Mycologia, 96(2), 2004, pp. 219-225.

(C) 2004 by The Mycological Society of America, Lawrence, KS 66044-8897

\title{
Succession of fungi on dead and live wood in brackish water in Brunei
}

\author{
S.C. Fryar ${ }^{1}$ \\ Centre for Research in Fungal Diversity, Department of \\ Ecology Eै Biodiversity, The University of Hong Kong, \\ Pokfulam Road, Hong Kong
}

J. Davies

W. Booth

School of Biology, Universiti Brunei Darusalam, Brunei Darusalam

I.J. Hodgkiss

K.D. Hyde

Centre for Research in Fungal Diversity, Department of Ecology Ẽ Biodiversity, The University of Hong Kong, Pokfulam Road, Hong Kong

Abstract: We observed the sequence of fungi appearing on submerged wood of Hibiscus tiliaceus that initially was either dead or alive. Branches that were dead, but still attached to the tree, and live branches were cut from $H$. tiliaceus in the riparian vegetation in a brackish habitat on the Tutong River, Brunei. Branch segments were connected to the riverbank using monofilament line. Samples were examined for fungi before the branches were placed in the river and after the branches had been submerged 3 or 6 mo. Fifty taxa were found on the samples. Before being placed in the water different fungal assemblages were found on live as compared to deadwood. Branches that were alive when cut supported a distinctly different fungal assemblage after 3 mo in the water. Dead branches after 3 mo and both dead and initially live samples after 6 mo had been colonized by a fungal assemblage that is typical at this site. It is unknown whether the differences in colonization of dead and initially live wood can be attributed to differences in the substratum (i.e., the presence or absence of bark), inhibitory substances in more recently live wood or to assembly rules resulting from the different fungi that already were present in dead and live branches.

Key words: aquatic, ascomycetes, brackish, colonization, fungi, ecology, Hibiscus tiliaceus, hyphomycetes, succession

\footnotetext{
Accepted for publication August 25, 2003.

${ }^{1}$ Corresponding author. E-mail: scfryar@bigpond.com
}

\section{INTRODUCTION}

Ecological succession is the process of temporal change in community composition (Morin 1999). However, to emphasise the importance of the mycelium of fungi, mycologists often have referred to fungal succession as "the sequential occupation of the same site by thalli (normally mycelia) either of different fungi or of different associations of fungi" (Rayner and Todd 1979). When wood falls onto the forest floor or into a stream or river, environmental conditions in and around the branch change and it is exposed to a new assemblage of fungi. The fungi already present in the branch may or may not be able to live in the branch under these new conditions and in the face of new competitors (Bärlocher 1980), mycoparasites (Howe and Suberkropp 1993) or mycophagous insects (Bärlocher 1985). The substratum and its surroundings change significantly; this disturbance initiates the process of resource succession. The mechanism of falling might influence the sequence of species colonization. When a branch dies and decays while still attached to the tree, the wood likely will differ significantly from a recently living branch that has snapped off in a strong wind. The aim of this study, therefore, was to observe the assemblages of species in live and dead branches that were still attached to a tree and to observe the different successional pathways once the branches were cut and submerged in the river.

A number of studies have been conducted on succession of fungi in aquatic habitats on seedlings (Newell 1976), leaves (Chamier and Dixon 1982, Tanaka 1991, Raghukumar et al 1995, Iqbal 1996), cut wood (Vrijmoed et al 1986a, Sivichai et al 2002) and mangrove wood (Tan et al 1989, Hyde 1991, Leong et al 1991). Various studies have found that colonization of wood by fungi in aquatic habitats is influenced by competitors (Fryar et al 2001), host (Vrijmoed et al 1986a, Tan et al 1989, Leong et al 1991, Sivichai et al 2002), fouling organisms on the surface of the wood (Vrijmoed et al 1986b), presence or absence of bark (Shearer and Webster 1991, Gönczöl and Révay 1993), wood block size (Sanders and Anderson 1979) and season (Willoughby and Archer 1973, Kirk and Brandt 1980, Vrijmoed et al 1982, Sarma and Vittal 2000). In addition, fungi have been found to interact with other organisms in wood. For 
TABLE I. Number of samples on which each species occurred in each treatment. $\mathrm{N}=$ total number of individuals, $\mathrm{S}=$ total number of species

\begin{tabular}{|c|c|c|c|c|c|c|c|c|c|c|c|c|}
\hline \multirow[b]{3}{*}{ Time (months) } & \multicolumn{6}{|c|}{ Dead } & \multicolumn{6}{|c|}{ Live } \\
\hline & \multicolumn{3}{|c|}{ Series 1} & \multicolumn{3}{|c|}{ Series 2} & \multicolumn{3}{|c|}{ Series 1} & \multicolumn{3}{|c|}{ Series 2} \\
\hline & 0 & 3 & 6 & 0 & 3 & 6 & 0 & 3 & 6 & 0 & 3 & 6 \\
\hline \multicolumn{13}{|l|}{ Ascomycetes } \\
\hline Annulatascus velatisporus & - & - & - & - & - & - & - & - & 1 & - & 1 & - \\
\hline Anthostomella sp. & - & - & - & - & - & - & - & 1 & - & - & - & - \\
\hline Aquaticola longicolla & 6 & - & - & 3 & - & - & 1 & - & 1 & - & - & - \\
\hline Ascotaiwania pallida & - & - & - & 2 & - & - & - & - & - & - & - & - \\
\hline Bruneiapiospora sp. & - & - & - & 1 & - & - & - & - & - & - & - & - \\
\hline Ceratosphaeria sp. 2 & - & 1 & - & - & - & - & - & - & - & - & - & - \\
\hline Ceratosphaeria sp. 3 & - & - & - & 1 & - & - & 1 & 2 & - & - & - & - \\
\hline Chaetosphaeria sp. & - & - & - & 1 & - & - & - & - & - & - & - & - \\
\hline Fluviatispora boothii & - & - & 6 & - & - & - & - & - & - & - & - & - \\
\hline Fluviatispora reticulata & - & - & 6 & - & 3 & - & - & - & 1 & - & 1 & - \\
\hline Lasiosphaeria immersa & - & 1 & 2 & - & 5 & 3 & - & - & 2 & - & - & - \\
\hline Lasiosphaeria sp. 1 & - & - & 9 & - & 1 & - & - & - & 12 & - & - & - \\
\hline Lasiosphaeria sp. 2 & 1 & - & - & - & - & - & - & 1 & - & - & - & - \\
\hline Leptosphaeria australiensis & - & - & - & 1 & - & - & - & - & - & - & - & - \\
\hline Lulworthia spp. & - & - & - & - & - & - & - & - & 2 & - & 8 & 1 \\
\hline Massarina rubi & 1 & - & - & 1 & - & - & - & - & - & - & - & - \\
\hline Massarina tetraploa & - & - & - & - & - & 1 & - & - & - & - & - & - \\
\hline Nectria haematococca & - & - & - & - & - & - & 20 & - & - & 24 & - & - \\
\hline New genus & - & - & - & - & 1 & - & - & - & - & - & - & - \\
\hline Orbilia sp. & 1 & - & - & 1 & - & - & - & - & - & - & - & - \\
\hline Phaeosphaeria sp. & 1 & - & - & - & - & - & - & - & - & - & - & - \\
\hline Sungaiicola brachydesmiella & - & 1 & 15 & - & 8 & 1 & - & - & 1 & - & - & - \\
\hline Swampomyces triseptatus & 1 & - & - & - & - & - & - & - & - & - & - & - \\
\hline Total Ascomycetes N & 11 & 3 & 38 & 11 & 18 & 5 & 22 & 4 & 20 & 24 & 10 & 1 \\
\hline & 6 & 3 & 5 & 8 & 5 & 3 & 3 & 3 & 7 & 1 & 3 & 1 \\
\hline \multicolumn{13}{|l|}{ Anamorphs } \\
\hline Arthrobotrys oligospora & 1 & - & - & 16 & - & - & 1 & - & 1 & - & - & - \\
\hline Berkleasmium sp. & 2 & - & - & - & - & - & - & - & - & - & - & - \\
\hline Beverwykella pulmonaria & - & - & 1 & - & - & - & - & - & - & 1 & - & - \\
\hline Brachysporiella gayana & - & - & - & - & - & 1 & - & - & - & - & - & - \\
\hline Cancellidium applanatum & - & 19 & 30 & - & 24 & 15 & - & 4 & 15 & - & 11 & 4 \\
\hline Coleodictyospora cubensis & 4 & - & - & 1 & - & - & 1 & - & - & - & - & - \\
\hline Conioscypha sp. & 1 & - & - & - & - & - & - & - & - & - & - & - \\
\hline Excerticlava vasiformis & - & - & 4 & - & 1 & - & - & - & 6 & - & 2 & - \\
\hline Graphium putredinsis & - & - & - & - & - & - & 14 & - & - & 6 & - & - \\
\hline Helicomyces sp. & - & - & 1 & - & - & - & - & - & - & - & - & - \\
\hline Intercalispora nigra & - & - & - & - & - & - & - & 1 & - & - & - & - \\
\hline Lasiodiplodia sp. & 2 & - & - & - & - & - & 8 & - & - & - & - & - \\
\hline Monodictys pelagica & 1 & 2 & - & 2 & - & - & 2 & 2 & 1 & - & - & - \\
\hline Monodictys sp. 1 & 13 & - & 2 & 1 & - & - & 1 & 1 & - & - & - & - \\
\hline Papulospora sp. 1 & - & - & - & - & 1 & - & 1 & - & 1 & - & 2 & 1 \\
\hline Papulospora sp. 2 & 1 & 3 & 4 & 2 & 3 & 1 & 2 & 6 & 8 & - & 1 & - \\
\hline Penicillium sp. & - & - & - & - & - & - & - & - & - & 1 & - & - \\
\hline Phaeoisaria clematidis & 4 & 1 & 5 & - & - & 1 & 1 & - & 1 & 1 & - & - \\
\hline phoma-like sp. & - & - & - & - & - & - & 1 & - & - & 6 & - & - \\
\hline Spacidoides sp. & - & - & - & - & - & 1 & - & - & - & - & - & - \\
\hline Sporidesmium cf anglicum & 4 & - & - & 4 & - & - & - & - & - & - & - & - \\
\hline Sporidesmium crassisporum & - & - & - & 1 & - & - & - & - & - & - & - & - \\
\hline Sporidesmium sp. 1 & 1 & - & - & - & - & - & - & - & - & - & - & - \\
\hline verticillium-like & - & - & - & - & - & - & 1 & - & - & 1 & - & - \\
\hline
\end{tabular}


TABle I. Continued

\begin{tabular}{|c|c|c|c|c|c|c|c|c|c|c|c|c|}
\hline \multirow[b]{3}{*}{ Time (months) } & \multicolumn{6}{|c|}{ Dead } & \multicolumn{6}{|c|}{ Live } \\
\hline & \multicolumn{3}{|c|}{ Series 1} & \multicolumn{3}{|c|}{ Series 2} & \multicolumn{3}{|c|}{ Series 1} & \multicolumn{3}{|c|}{ Series 2} \\
\hline & 0 & 3 & 6 & 0 & 3 & 6 & 0 & 3 & 6 & 0 & 3 & 6 \\
\hline Xylomyces chlamydosporopsis & - & 3 & - & - & - & - & - & - & - & 1 & - & - \\
\hline Xylomyces giganteus & - & - & - & - & 1 & - & - & - & - & - & 1 & - \\
\hline Xylomyces sp. & - & 1 & - & - & 1 & 2 & - & 5 & 2 & - & 1 & - \\
\hline Total anamorphs $\mathrm{N}$ & 33 & 29 & 47 & 27 & 31 & 21 & 33 & 19 & 35 & 17 & 18 & 5 \\
\hline $\mathrm{S}$ & 11 & 6 & 7 & 7 & 6 & 6 & 11 & 6 & 8 & 7 & 6 & 2 \\
\hline Total N & 44 & 26 & 85 & 38 & 49 & 26 & 55 & 23 & 55 & 41 & 28 & 6 \\
\hline Total S & 17 & 9 & 12 & 15 & 11 & 9 & 14 & 9 & 15 & 8 & 9 & 3 \\
\hline
\end{tabular}

example, fungi precondition wood for colonization of marine borer larvae (Grasso et al 1985).

The influence of the state of the wood on fungal assemblages before submergence has not been studied. Many studies on wood succession have used either sawn timber (e.g., Vrijmoed et al 1986a) or branches that have been split into segments (e.g., Tan et al 1989, Leong et al 1991). When a branch falls into the water, it usually falls intact, apart from the spot where it broke from the tree. We therefore chose to submerge branch segments intact, except at the ends. Most studies of the succession of colonization of wood have been conducted either in the open sea or in mangroves. Therefore, we chose to investigate the process in a brackish habitat.

\section{MATERIALS AND METHODS}

Study area.-Sungai Kelakas is a tributary of the Tutong River, Brunei. At the site $\left(04^{\circ} 49.8^{\prime} \mathrm{N}, 114^{\circ} 42.1^{\prime} \mathrm{E}\right)$, Sungai Kelakas is approximately $20 \mathrm{~m}$ wide and $2 \mathrm{~m}$ deep in the deepest part. The tributary is tidal, with salinity and temperature ranging respectively from $0-12 \%$ and 26-30 C. During the study, dissolved oxygen in the tributary was low (20-45\%, 1.5-3.5 $\mathrm{mgL}^{-1}$ ) and acidic ( $\left.\mathrm{pH} 4.8-6.0\right)$. The tributary is bordered by a riparian strip approximately $50 \mathrm{~m}$ wide. The strip is inundated to a maximum depth of $0.5 \mathrm{~m}$ at high river volume (when the water is fresh) and during high tides. The vegetation is a mixture of Barringtonia $\mathrm{cf}$. racemosa, Bruguiera gymnorrhiza, Cerbera odallam, Ficus cf. microcarpa, Gluta velutina, Heritiera globosa, Hibiscus tiliaceus, Nypa fruticans and Sonneratia caseolaris.

Experimental design.-Branches that were dead but attached and live branches of a Hibiscus tiliaceus tree at the site were cut down and removed. Those branches were high in the tree and would not have been submerged by water at any stage. The branches were cut into $10 \mathrm{~cm}$ lengths, and holes were drilled into each end of each branch segment. The branch segments ranged from 0.5 to $3 \mathrm{~cm}$ diam and randomly were divided into six groups (30 dead and 30 live per group). One group was taken to the laboratory and incubated immediately. Other groups were placed in the stream using the following design. Monofilament line was threaded through each of the branch segments so that the 30 samples from each group formed two ladders of 15 samples each. Samples were submerged in the Tutong 16 Aug 1998 (Series 1 exposure). This design was repeated 3 mo later at the same site, using the same tree, and the samples were submerged 27 Oct 1998 (Series 2 exposure). Samples were positioned $0.1-1 \mathrm{~m}$ deep so that they would not be exposed at low tide.

Samples were recovered after 3 and 6 mo. The samples taken immediately were not submerged. Thirty dead branch segments (D) and 30 segments cut live (L) from each of the two experimental series were recovered at each sampling time by randomly taking three branch segments from each of the ladders. It was intended that the remaining samples would be recovered after 18 mo. However, the site was disturbed and the samples were lost before samples could be collected.

Samples were washed briefly to remove any mud, then put individually into sterile $10 \times 10 \mathrm{~cm}$ plastic bags, labeled, sealed and returned to the laboratory to be incubated at $27 \mathrm{C}$, which represented the average temperature of the river, under a $12 \mathrm{hr}$ light/12 hr dark cycle to induce sporulation. Five $\mathrm{mL}$ of sterile distilled water was added to each bag. Specimens were examined under a $400 \times$ dissecting microscope after 2 wk of incubation. Fruiting bodies appearing on the surface of the wood were identified and cultured. Specimens were lodged in the HKU(M) herbarium. Cultures were lodged in HKUCC.

Data analysis.-Two-way ANOVA was used to detect difference in the number of species per branch in each between samples.

Multivariate analysis.-Detrended Correspondence Analysis (DCA) (Kent and Coker 1992) was used to detect differences in species abundance between sample sets. MultiVariate Statistical Package (MVSP) (www.kovcomp. com/mvsp) was used.

\section{RESULTS}

Decomposition of samples.-At the time the samples were submerged, both dead and live-cut branches 


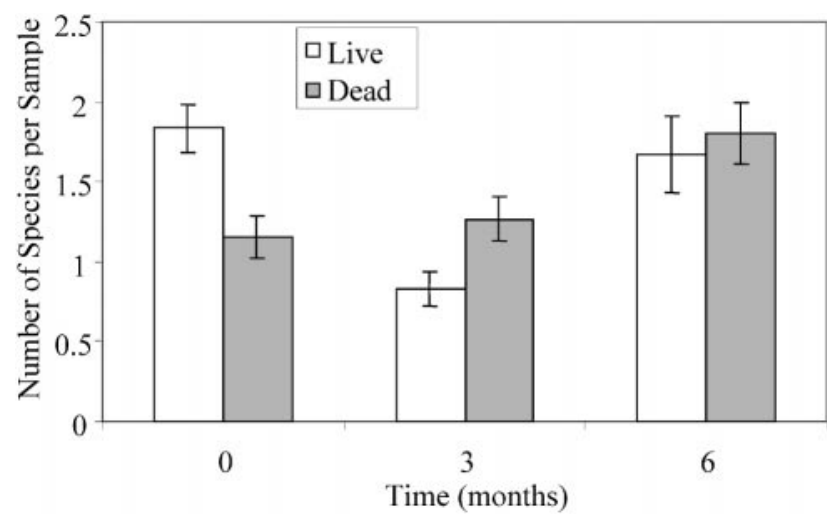

FIG. 1. Average number of species found on each set of samples. Error bars $= \pm$ S.E.M.

were intact, except at both ends of each. After 3 and 6 mo in the water, some of the dead branches either had lost bark or the bark was loose; in some the bark was intact. Live-cut branches had not lost bark after 6 mo in the water.

Species.-A total of 23 ascomycetes and 27 anamorphic fungi were found on the samples (TABLE I). Overall, the most common taxa were Cancellidium applanatum $(\mathrm{N}=122)$, Haematonectria haematococca $(\mathrm{N}=44)$, Sungaiicola brachydesmiella $(\mathrm{N}=26)$ and Lasiosphaeria sp. $1(\mathrm{~N}=22)$. Cancellidium applanatum was common on all samples after submergence. Haematonectria haematococca occurred only on livecut branches before submergence. Sungaiicola brachydesmiella was found mostly on dead branches after submergence.

Live-cut branches frequently were inhabited by Graphium putridensis, Lasiodiploda sp., Haematonectria haematococca and a Phoma-like species. After submergence for 3 mo, live-cut branches mainly supported Cancellidium applanatum, Papulospora sp. 2 and various other species that did not tend to occur on branches before submergence.

Dead branches frequently were inhabited by Aquaticola longicola, Arthrobotrys oligospora, several Monodictys species and Sporidesmium cf. anglicum before submergence. After 3 mo in the water, dead branches supported Cancellidium applanatum, Lasiosphaeria immersa, Sungaiicola brachydesmiella, Papulospora sp. 2 and various other species that did not tend to occur on the branches before submergence.

After 6 mo in the water, Cancellidium applanatum, Exserticlava vasiformis, Fluviatispora boothii, F. reticulata, Lasiosphaeria immersa, Lasiosphaeria sp. 1, Sungaiicola brachydesmiella and Papulospora sp. 2 were frequent colonizers of both dead and live-cut samples. These and other species also occurred on submerged dead branches after 3 mo.

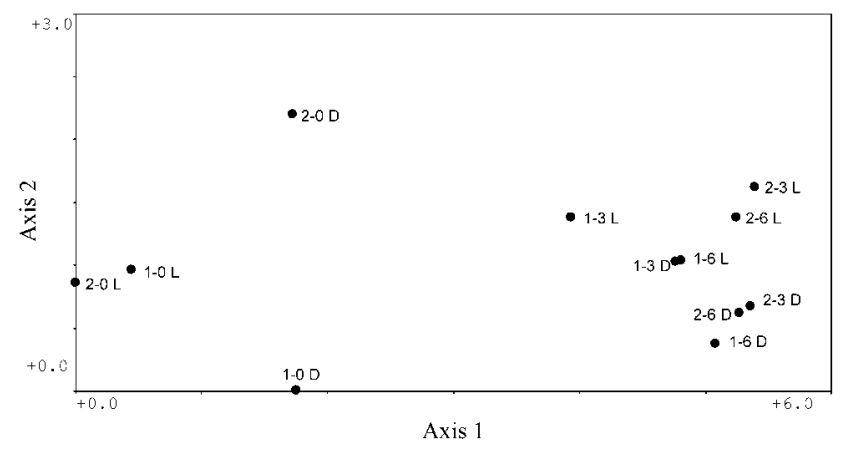

FIG. 2. Plot of axis1 versus axis 2 scores from Detrended Correspondence Analysis including samples that were not placed in the water.

An average of 1.42 species sporulated on each sample. However, there was considerable variation between samples $(\mathrm{SD}=0.62)$. Eighty-six samples $(22 \%)$ had no fungi at all, whereas some samples contained up to six species. Two-way ANOVA demonstrated a significant interaction in the number of species per sample between the time of submergence and whether the branch sample was live cut or dead (FIG. 1, $\mathrm{F}_{1,2}$ $=7.4, P=0.001)$. Live-cut samples supported fewer species after 3 mo of exposure, but the number of species per sample increased after 6 mo. Dead samples initially supported fewer species than live-cut samples, but unlike the live-cut samples, the number of species did not decrease after 3 mo. The number of species recovered from the dead samples, however, did increase after 6 mo.

Correlations among species.-The occurrence of each species on each branch was tested for correlation with all other species in that sample. No negative correlations we found. Most positive correlations were found between pairs of species in which at least one occurred only once in that sample. These correlations are not reliable and, therefore, are not shown. Further observations of these species would be needed to establish a connection between the two species. The only correlation that involved more than one occurrence of each species were Cancellidium applanatum and Excerticlava vasiformis on dead samples in Series 1 exposure collected after 6 mo (1-6 D).

Multivariate analysis.-In the Detrended Correspondence Analysis (DCA), the first two axes explained $36 \%$ of the variation in the samples. Unsubmerged live-cut branch samples (1-0L and 2-0L) grouped together as did unsubmerged dead branch samples (1OD and 2-0D) (FIG. 2). All other samples clustered together, but with live-cut branch samples collected after 3 mo (1-3L and 2-3L) slightly toward the outside of the group. When the samples taken before any time had elapsed were removed from the dataset, two 


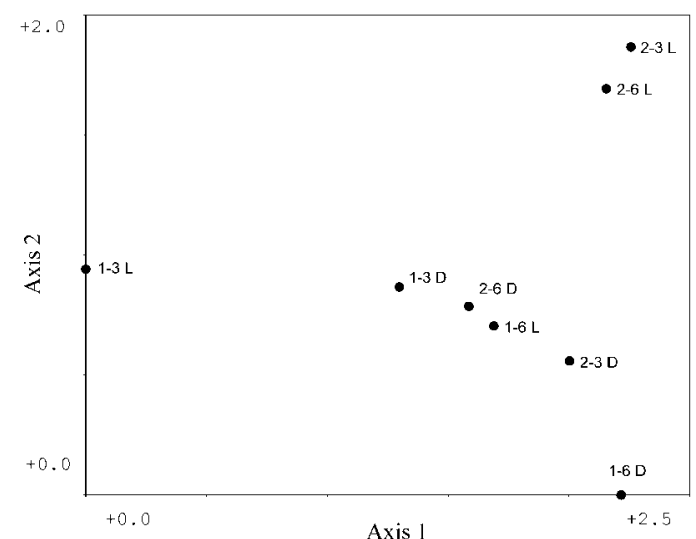

FIG. 3. Plot of axis1 versus axis 2 scores from Detrended Correspondence Analysis exluding samples that were not placed in the water.

sample sets (1-3L and 2-3L) were distinctly separate from the other samples (FIG. 3). In ecological terms, there were different assemblages of fungi on unsubmerged live-cut and deadwood samples at the beginning of the experiment. After 3 mo in the water, livecut branches had a different assemblage of fungi, compared to dead branches. After 6 mo of submergence, dead and live-cut branches tended to have similar assemblages, which were similar to the assemblage on dead branches after 3 mo.

\section{DISCUSSION}

As expected, there was a succession of species colonizing the samples placed in the river. The fungi present before submergence usually disappeared or were found infrequently after 3 mo in the water. Generally, none of the original fungi were present after 6 mo. There were exceptions; a few specimens of some species survived (e.g., Arthrobotris oligospora, Monodictys sp. 1, Monodictys pelagica, Papulospora sp. 1, Phaeoisaria clematidis). This is consistent with previous studies where nonaquatic fungi were found in wood after 2 mo in the water but not after 6 mo (Shearer and Webster 1991).

After 3 mo in the river, a marked difference was noted between the fungal assemblage on dead branches and that on live-cut branches. This difference might be attributed to the differences in substratum rather than the assemblage of fungi already present in the sample. Some dead-branch samples lost their bark after time in the river, which might have contributed to differences in fungal assemblages. For example, Gönczöl and Revay (1993) found a slightly different assemblage of fungi colonizing twigs with and without bark. However, inhibitory substances in fresh plant tissue might affect fungal assemblag- es. Gessner et al (1993) found that fresh leaves were colonized more slowly by aquatic fungi than dead, dry leaves; the difference was attributed to inhibitory compounds in fresh leaves.

It is interesting to note that the two sets of live-cut samples collected after 3 mo carried different fungal assemblages even though they originally had similar fungal assemblages. The cause is unknown, although seasonal differences might have played a part.

After 6 mo, dead and live-cut branches carried similar fungal assemblages. This assemblage was very similar to the fungi found on naturally occurring samples at the same site (Fryar unpubl). For example, Sungaiicola brachydesmiella and Cancellidium applanatum were common on all samples. Colonization of dead branches tended to be similar to this assemblage after only 3 mo. Colonization by these fungi might not have occurred on live-cut branches for the reasons discussed above.

Although the succession of colonization could be caused by differences in the substratum, it is possible that the differences could be due in part to the fungi on samples before submergence. It has been shown that pre-inoculation of wood by fungi can influence the colonization of that wood by subsequent fungi (Shearer 1995, Fryar et al 2001). However, the fungi in these experiments were from an aquatic habitat and therefore would be expected to be competitive in that environment. It is unknown whether nonaquatic fungi pre-existing in a piece of wood can influence the colonization by aquatic fungi once the wood has fallen into the water.

Fungal succession studies in aquatic habitats have had a recurring problem. Some studies have used the techniques of stringing ladders of branch segments together or placing samples together in mesh bags. However, only one string or bag of samples were removed per sampling (e.g., Willoughby and Archer 1973, Tanaka 1991, Raghukumar et al 1995, Iqbal 1996). This means that there was only one replicate per sampling time. Different samples on the same ladder would be pseudoreplicates (see Hurlbert 1984, Underwood 1997). Some other studies (including this one) have avoided this problem by removing only one or a few samples from each ladder or bag per sampling (e.g., Newell 1976, Vrijmoed et al 1986a, Tan et al 1989, Leong et al 1991, Garnett et al 2000) or by removing multiple replicate ladders or bags per sampling (e.g., Gessner et al 1993). Methods to study aquatic fungal succession are discussed by Pointing et al (2000) and Fryar (2002).

Seasonality has been known to influence the colonization of substrata by aquatic fungi (Willoughby and Archer 1973, Kirk and Brandt 1980, Vrijmoed et al 1982). In this study two parallel experiments were 
run, starting at different times of the year. Although differences were found between the two experimental series, no inferences can be made with regard to seasonality. Differences simply might be due to natural variation.

Haematonectria haematococca was found commonly on live samples before before submergence but not after. Shearer and von Bodman (1983) also found Nectria haematococca $(=H$. haematococca) on samples that were submerged (but also had been cut recently from a live tree or recently had fallen). Willoughby and Archer (1973) found Nectria lugdunensis on twigs that had been submerged 1-4 mo but did not find it after that time, while Ho et al (2002) found several species of Nectria to be early colonizers of submerged wood. Species of Nectria sens. lat. are common terrestrial fungi, often growing on other fungi, bark and wood (Samuels 1976) and do not appear to survive well in the aquatic habitat.

Cancellidium applanatum was common on all samples placed in the water and also on samples in a general survey conducted simultaneously (Fryar unpubl). This aero-aquatic hyphomycete originally was described from balsawood test blocks from a lake in Japan (Tubaki 1975). However, it since has been recovered from submerged decaying leaves in Malaysia (Webster and Davey 1980) and Queensland, Australia (Shaw 1994). It had not been recorded previously in Brunei.

\section{ACKNOWLEDGMENTS}

We would like to thank the Department of Forestry, Brunei, for allowing collection of wood samples. This work was completed under a University of Hong Kong Postdoctoral Fellowship and financing was provided by a CRCG grant (Hong Kong University).

\section{LITERATURE CITED}

Bärlocher F. 1980. Leaf-eating invertebrates as competitors of aquatic hyphomycetes. Oecologia 47:303-306.

- 1985. The role of fungi in the nutrition of stream invertebrates. Bot J Linn Soc 91:83-94.

Chamier AC, Dixon PA. 1982. Pectinases in leaf degradation by aquatic hyphomycetes I: the field study. The colonization-pattern of aquatic hyphomycetes on leaf packs in a Surrey Stream. Oecologia 52:109-115.

Fryar SC. 2002. Fungal succession or sequence of fruit bodies? Fung Divers 10:5-10.

—, Tsui KM, Hodgkiss IJ, Hyde KD. 2001. The influence of competition between tropical fungi on wood colonization in streams. Microbial Ecology 41:245-251.

Garnett H, Bärlocher F, Giberson D. 2000. Aquatic hyphomycetes in Catamaran Brook: colonization dynamics, seasonal patterns, and logging effects. Mycologia 92: 29-41.
Gessner MO, Thomas M, Jean-Louis A, Chauvet E. 1993. Stable successional patterns of aquatic hyphomycetes on leaves decaying in a summer cool stream. Mycol Res 97:163-172.

Gönczöl J, Révay A. 1993. Further studies on fungal colonization of twigs in the Morgo-stream, Hungary. Nova Hedwigia 56:531-542.

Grasso S, La Ferla R, Jones EBG. 1985. Lignicolous marine fungi in a harbour environment (Milazzo). Bot Mar 28: 259-264.

Ho WH, Yanna, Hyde KD, Hodgkiss IJ. 2002. Seasonality and sequential occurrence of fungi on wood submerged in Tai Po Kau Forest Stream, Hong Kong. Fung Divers 8:21-43.

Howe MJ, Suberkropp K. 1993. Effects of mycoparasitism on an aquatic hyphomycete growing on leaf litter. Mycologia 85:898-901.

Hurlbert SJ. 1984. Pseudoreplication and the design of ecological field experiments. Ecol Monogr 54:187-211.

Hyde KD. 1991. Fungal colonization of Rhizophora apiculata and Xylocarpus granatum poles in Kampong Kapok mangrove, Brunei. Sydowia 43:31-38.

Iqbal SH. 1996. Species diversity of freshwater hyphomycetes in some streams of Pakistan. III. Autumnal colonization of freshwater hyphomycetes on bait leaves. Mycoscience 37:121-128.

Kent M, Coker P. 1992. Vegetation description and analysis: a practical approach. London: Belhaven Press. 363 p.

Kirk PW, Brandt JM. 1980. Seasonal distribution of lignicolous marine fungi in the lower Chesapeake Bay. Bot Mar 13:657-668.

Leong WF, Tan TK, Jones EBG. 1991. Fungal colonization of submerged Bruguiera cylindrica and Rhizophora apiculata wood. Bot Mar 34:69-76.

Morin PJ. 1999. Community ecology. Malden: Blackwell. $424 \mathrm{p}$.

Newell SY. 1976. Mangrove fungi: the succession in the mycoflora of Red Mangrove (Rhizophora mangle L.) seedlings. In: Jones EBG, ed. Recent advances in aquatic mycology. London: Elek Science. p 51-91.

Pointing SB, Fryar SC, Hyde KD, Mouzouras R. 2000. Assessment of wood decay, fungal interactions and colonisation. In: Hyde KD, Pointing SB, eds. Marine mycology-a practical approach. Fungal Diversity Research Series 1, Hong Kong: Fungal Diversity Press. p 113-136.

Raghukumar S, Sathe-Pathak V, Sharma S, Raghukumar C. 1995. Thraustochytrid and fungal component of marine detritus. III. Field studies on decomposition of leaves of the mangrove Rhizophora apiculata. Aquat Microb Ecol 9:117-125.

Rayner ADM, Todd NK. 1979. Population and community structure and dynamics of fungi in decaying wood. Adv Bot Res 7:333-420.

Samuels GJ. 1976. A revision of the fungi formerly classified as Nectria subgenus Hyphonectria. Mem New York Bot Gard 26(3):1-126.

Sanders PF, Anderson JM. 1979. Colonization of wood blocks by aquatic hyphomycetes. Trans Brit Mycol Soc 73:103-107. 
Sarma VV, Vittal BPR. 2000. Biodiversity of mangrove fungi on different substrata of Rhizophora apiculata and Avicennia spp. from Godavari and Krishna deltas, east coast of India. Fung Divers 5:23-41.

Shaw DE. 1994. The aero-aquatic fungus Cancellidium applanatum K. Tubaki in Queensland. Mycologist 8:162163.

Shearer CA. 1995. Fungal competition. Can J Bot 73 (Suppl. 1):S1259-S1264.

- von Bodman SB. 1983. Patterns of occurrence of ascomycetes associated with decomposing twigs in a midwestern stream. Mycologia 75:518-530.

-, Webster J. 1991. Aquatic hyphomycete communities in the river Teign. IV. Twig colonization. Mycol Res 95: 413-420.

Sivichai S, Jones EBG, Ht-Jones NL. 2002. Fungal colonisation of wood in a freshwater stream at Tad Ta Phu, Khao Yao National Park, Thailand. Fung Divers 10: 113-129.

Tan TK, Leong WF, Jones EBG. 1989. Succession of fungi on wood of Avicennia alba and A. lanata in Singapore. Can J Bot 67:2686-2691.

Tanaka Y. 1991. Microbial decomposition of reed (Phrag- mites communis) leaves in a saline lake. Hydrobiologia 220:119-129.

Tubaki K. 1975. Notes on the Japanese Hyphomycetes VII. Cancellidium, a new Hyphomycete genus. Trans Mycol Soc Japan 16:357-360.

Underwood AJ. 1997. Experiments in ecology: their logical design and interpretation using analysis of variance. Cambridge University Press, Cambridge. 504 p.

Vrijmoed LLP, Hodgkiss IJ, Thrower LB. 1982. Seasonal patterns of primary colonization by lignicolous marine fungi in Hong Kong. Hydrobiologia 89:253-262. ,--1 . 1986a. Occurrence of fungi on submerged pine teak blocks in Hong Kong coastal waters. Hydrobiologia 135:109-122.

1986b. Effects of surface fouling organisms on the occurrence of fungi on submerged pine blocks in Hong Kong coastal waters. Hydrobiologia 135:123-130.

Webster J, Davey A. 1980. Two aero-aquatic hyphomycetes from Malaysia. Trans Brit Mycol Soc 75:341-345.

Willoughby LG, Archer JF. 1973. The fungal spora of a freshwater stream and its colonization pattern on wood. Freshwater Biol 3:219-239. 